МИЛА ТУРАЈЛИЋ

Универзитет у Београду,

Факултет политичких наука, Београд

$$
\begin{aligned}
& \text { DOI 10.5937/kultura1546061T } \\
& \text { УДК 930.1:316.75(497)"198/..." } \\
& \text { 791.227.2(497.1) } \\
& \text { 316.722(497.1):930.1 } \\
& \text { 321.74:929 Тито }
\end{aligned}
$$

оригиналан научни рад
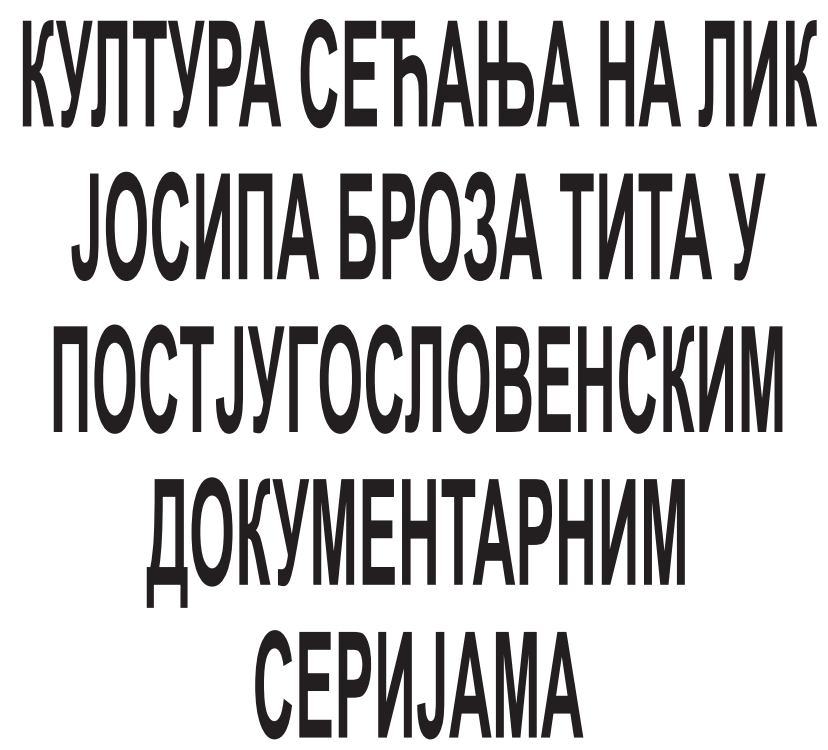

\footnotetext{
Сажетак: Циљ овог рада је анализа политике репрезентације лика Председника Јосипа Броза Тита у најзначајнијим телевизијским серијама у периоду после 2000. године. Након кратког прегледа улоге коју је аудиовизуелна слика (филмска, а затим телевизијска) играла у изградњи Титовог култа личности у периоду СФРЈ, главни део рада се анализом тематског и наративног садржаја релевантних ТВ серија бави начином на који су наслеђени дискурси из периода сочијализма прошли кроз политичку и друштвену транзииију. Критички сумирајући променљиво значење приказа Титовог лика у контексту конструкиије и ре-конструикије културе сећања у главном делу рада се диференцирају постојећи националистичкопатриотски и конзумеристички приступи.
}

Кључне речи: култура сећања, документарни филм, ТВ серија, Јосип Броз Тито, култ личности, (пост)југословенски наративи 


\section{Нацฺја као културна конструкичија}

У радовима политиколога и социолога који су се бавили идентификацијом друштвених процеса формирања осећања националне припадности, улога коју је играла филмска слика је (за сада) недовољно анализирана. Традиционалне теорије формирања нације (у смислу изградње државе на националним основама) и националног идентитета су окренуте ка историјском пореклу нације, а ређе ка критичкој анализи начина на које се појам или осећај припадања нацији формулише и доживљава кроз популарну културу и свакодневни живот. Ово питање је од посебног значаја у ситуацијама транзиције и друштвене трансформације, као што су распад и настајање нових националних држава. Управо због таквог угла посматрања, у теорији културе је уочљив недостатак истраживања о томе како су одређене националне културе конструисане у сфери јавне комуникације, и како се кроз идентификацију промене тема и наратива културних производа, у овом случају документарних и играних филмова и телевизијских серија, могу уочити главни токови постсоцијалистичке транзиције.

У анализи начина на који филм доприноси стварању визуелних слика и наратива који омогућавају једној заједници да се осети припадницима (имагинарне) нације, Тим Кенеди (Тim Kennedy) тврди да „национално сећање лежи у самом срцу националног идентитета" ${ }^{1 "}$, а национално сећање пак дефинише као фонд прича кроз које се артикулише нација, које се могу описати и одредницом - колективно сећање. Развијајући концепт колективног сећања, социолог Морис Албваш (Maurice Halbwachs) је међу првима указао на чињеницу да сећање увек функционише у контексту данашњице, тврдећи да се колективне репрезентације прошлости „стварају и прекрајају у садашњости за потребе садашњости". ${ }^{2}$ Албваш истиче инструменталност у причању заједничке прошлости, то јест, да ти наративи настају да би служили одређеној сврси, и у одређеном историјском контексту ${ }^{3}$ Француски историчар Пјер Нора (Pierre Nora), који је проучавао начин на који је француска историја артикулисана кроз стварање

1 Kennedy, T. (2007) Cinema Regarding Nations: Re-imagining Armenian, Kurdish, and Palestinian national identity in film, doctoral dissertation, Department of Film, Theater \& Television, University of Reading, p. 38.

2 Olick, J. K. (2007) From Usable Pasts to the Return of the Repressed, The Hedgehog Review: Critical Reflections on Contemporary Culture, Summer 07, Virginia: Institute for Advanced Studies in Culture, p. 19. За оригинални текст видети: Halbwachs, М. On Collective Memory, trans. and ed. Coser, L. (1992) Chicago: University of Chicago Press.

3 Исто, стр. 20. 
званичне комеморативне културе, користи термин 'места ceћања' (lieux de mémoire) да опише институције као што су школе, универзитети, музеји и архиве, али и физички ентитети попут споменика и имена улица, кроз које колективно или јавно сећање бива 'упрегнуто' у стварању модерне нације. ${ }^{4}$ Сви они заједно заправо конструишу национални наратив који се људима прича кроз књижевност, медије и визуелну уметност, а филмски наративи су један од кључних носилаца тог репертоара прича и митова.

Пишући о националним кинематографијама, Сјузан Хејвард (Susan Hayward) пружа теоријско становиште са ког би се кинематографија могла анализирати не као „чист и једноставан одраз историје ${ }^{5 "}$ већ управо као трансформација историје, управо стога што филм функционише као културолошка артикулација нације. Ако се прихвати теза коју је поставио Нора, а то је да филмови нису само 'складиште сећања', већ и докази његове 'фабрикације ' онда се отвара простор за анализу шта и како се мења у филмским наративима у тренуцима када колективно сећање бива избрисано, као што је то случај у пост-социјалистичким друштвима.

У студији совјетског филма и улоге коју он данас игра у постсовјетском друштву, Евгениј Добренко (Evgeny Dobrenko) предлаже два нивоа посматрања филмова, као инструменте производње историје, то јест као политичко-естетички пројекат којим је конструисан наратив историје, чиме су се слике прошлости трансформисале у кохерентна значења чији је циљ био мобилизација совјетске публике, али у исто време и као 'музеј револуције', односно извор истих тих слика прошлости за данашњу пост-совјетску публику. „Због тога ми не причамо толико о 'пропаганди' кроз уметност, већ о функцији стварања културе коју су ти артефакти имали. Филм, као најконститутивнија и најразвијенија уметничка пракса у стаљинистичкој култури, се овде посматра у својој улози као институција за производњу историје $\mathrm{7}^{7}$. Управо овај теоријски оквир, који поставља филмске наративе у оквир стварања нације и колективног сећања, представља полазну тачку анализе у овом раду.

4 Nora, P. (1984) Entre Mémoire et Histoire - La problématique des lieux, dans Les lieux de mémoire (Vol. 1), Paris: Gallimard.

5 Hayward, S. Framing National Cinemas, in: Cinema and Nation, eds. Hjort, M. and MacKenzie, S. (2005) London: Routledge, p. 84.

6 Nora, Р., нав. дело.

7 Dobrenko, E. (2008) Stalinist Cinema and the Production of History: Museum of the Revolution, Edinburgh: Edinburgh University Press, p. 1. 


\section{Политичка улога филмске слике у Југославији}

Председник Јосип Броз Тито (1895-1980) дошао је на власт у Југославији као вођа НОБ-а против немачке окупације током Другог светског рата. Од успостављања социјалистичке Југославије (ФНРЈ, од 1963. године СФРЈ), све до његове смрти 1980. године, Тито је представљао централну фигуру југословенског пројекта, чији је циљ био да изгради Југославију као државу која почива на два основна принципа, а то су социјалистички политички и економски систем спојен са федерацијом која уједињује шест република око концепта 'братства и јединства' (уместо концепта наднационалног идентитета).

Базирајући се на терминологији коју је поставио Бенедикт Андерсон (Benedict Anderson), Југославија се може тумачити као 'имагинарна заједница' чија се интеграција остваривала стварањем заједничких политичких митова. Ендру Вахтел (Andrew Wachtel), који је детаљно проучавао кључну улогу културе у стварању националног идентитета у Југославији, допуњује Андерсонов аргумент сматрајући да је национална култура средство којим се изражавају ,јасно артикулисане националне визије", односно идеологија социјалистичког друштва у спрези са заједничком прошлошћу која надилази различите етницитете кроз братство и јединство. Слично томе, Зала Волчић указује на то да је културни простор заузимао централно место у Југославији: „Конкретно, пан-југословенски филмови (и касније ТВ серије) били су од кључног значаја у мобилизацији осећаја југословенског идентитета9". Инсистирајући на томе да је овај пројекат југословенска политичка елита свесно развијала, Вахтел скреће пажњу да је управо социјалистички период био ,једини период у југословенској историји када је власт била централно ангажована у развијању и спровођењу културне политике ${ }^{10}$ ". Кључну улогу у тој новој културној политици играла је југословенска кинематографија, која је одмах по завршетку другог светског рата уздигнута са статуса робе намењене тржишту масовне забаве и добила положај културно-уметничког добра.

У студији коју је објавио 1985. године, Данијел Гулдинг (Daniel Goulding) анализира идеолошке и естетичке принципе који су обликовали југословенску кинематографију и

8 Wachtel, A. B. (1998) Making a Nation, Breaking a Nation: Literature and Cultural Politics in Yugoslavia, Stanford: Stanford University Press, p. 3.

9 Volčić, Z. (2007) Yugo-Nostalgia: Cultural Memory and Media, in the Former Yugoslavia, Critical Studies in Media Communication, 24:1, p. 23.

10 Wachtel, А. В., нав. дело, p. 9. 
поставља тезу да је за послератне југословенске политичке вође, филм испуњавао задатке социјалистичке изградње тиме што је „неговао прикладне ставове ${ }^{11}$ ”. Гулдинг дефинише основне тематске правце такве кинематографије као глорификацију револуционарне прошлости, реификацију Тита као врховног вође Југославије, и ,јачање револуционарног елана у изградњи нове социјалистичке државе"12, чиме заправо идентификује темељне политичке митове СФРЈ. Уписујући овакве филмове у званичну комеморативну културу, историчар филма Невена Даковић описује неке од ових генеричких модела, као што је серија партизанских филмова, а пре свега ратни спектакли Битка на Неретви (Вељко Булајић, 1969) и Сутјеска (Стипе Делић, 1973), као „целулоидне споменике”13 рату и револуцији.

\section{Визуелни култ Тита}

Личност Јосипа Броза Тита и њој придружен култ личности били су основни унификујући елемент у стварању осећања заједнице међу грађанима Југославије. Проучавајући иконографију Јосипа Броза Тита у контексту званичне визуелне културе социјалистичког периода, Бојана Пејић истиче начин на који је визуелни приказ Тита - његова слика активно учествовала у стварању идеје и колективне представе познате као 'Тито'. У том контексту, Титов лик постаје носилац југословенског мита, а његова присутност носилац континуитета југословенске заједнице. Тиме развој фонда прича, ритуала и симбола који се везују за Тита, а пре свега учестало приказивање његовог лика служе политичкој сврси, јер је оно носилац друштвеног устројства. Другим речима, Маја Бркљачић тврди да „друштвено тело југословенског друштва настаје у тренутку када оно посматра Титов лик"14 - тиме преклапајући оно што је Титова историја са историјом Југославије, чиме Тито постаје симбол заједничке историје.

У историји југословенског филма, у периоду од 1945. године до његове смрти, Тито је предмет великог броја документарних филмова, ванредних бројева филмских журнала и

11 Goulding, D. J. (2002, 2nd) Liberated Cinema. The Yugoslav Experience 1945-2001, Bloomington: Indiana University Press, p. 7.

12 Исто, стр. XIV

13 Daković, N. Out of the Past: Memories and Nostalgia in (Post)Yugoslav Cinema, in: Past for the Eyes: East European Representations of Communism in Cinema and Museums after 1989, eds. Sarkisova, O. and Apor, P. (2008) Budapest: CEU Press, p. 14.

14 Brkljačić, M. (2002) Tito's Bodies in Word and Image, Narodna Umjetnost, br. 40(1), p. 115. 
прилога у редовним филмским журналима. Од укупно 2.311 бројева журнала Филмских новости, Титу је посвећено више од половине (1.282 сторије), али се у домаћем ${ }^{15}$ играном филму његов лик појављује само три пута. Прво Титово 'појављивање’ на филмском платну је у филму редитеља Фадила Хаџића Десант на Дрвар (1963). У овом играном филму архивски документарни снимци Тита испред пећине изнад Дрвара су умонтирани у играну причу, а на метафилмском нивоу, тај први приказ Титовог лика у домаћем играном филму се дешава користећи прве постојеће документарне снимке Тита које је направила Британска војна мисија у Дрвару. Друго појављивање Титовог лика је 1972. године у филму Сутјеска, у режији Стипе Делића, који третира пету офанзиву на Сутјесци приликом које је Тито рањен, а где његов лик тумачи велшки глумац Ричард Бартон (Richard Burton). Последње појављивање његовог лика (за његовог живота ${ }^{16}$ ) је 1974. године у још једном ратном филму, Ужичка Република (Жика Митровић), где његов лик тумачи глумац Марко Тодоровић, али у овом филму наративни ток у ком се појављује Титов лик рађен је у документарном стилу, и његово појављивање је без речи. Занимљиво је нагласити да је у играним филмовима за Титовог живота његов лик третиран искључиво у периоду НОБ-а, не залазећи ни у теме Титове младости, нити у његову државничку улогу после рата. У том смислу су документарни пројекти отишли знатно даље, попут ТВ серије Вељка Булајића Титови мемоари, које је исцрпно обрадила Титова сећања на рано детињство (чије снимање је почело 1972. а није завршено), или документарног филма са интимистичким приступом попут $\mathrm{Tu}$ то Крсте Шканате (1980), који је свечано отворио пулски фестивал пар месеци након Титове смрти.

У својој студији о Титу, Тодор Куљић упозорава да „свака анализа овога режима мора имати на уму да поред (а) објективне титоистичке прошлости постоји и (б) симболички реконструисана и (ц) идеологизована прошлост титоизма ${ }^{17 "}$. Титов визуелни култ, изражен у филму, пружа увид у улогу коју филмске слике играју у конструкцији и деконструкцији политичких митова у социјализму и пост-социјализму.

15 Титов лик појављује се и у совјетском играном филму $У$ планинама Југославије (В горах Югославии, Абрахм Рохом, 1946), што је и први играни филм снимљен на простору Југославије после Другог светског рата, где га је тумачио руски глумац Иван Берсењев (Иван Николаевич Берсенев).

16 За Титовог живота почеле су припреме и за играни филм Игмански мари (Здравко Шотра, 1983) у ком га игра Лазар Ристовски. Филм је имао премијеру тек 1983. године.

17 Kuljić, T. (2011) Sećanje na titoizam, Beograd: Čigoja., str. 3. 


\section{И после Tuта, Tumo ${ }^{18}$}

У различитим теоријским анализама о распаду Југославије, Титова смрт (4. маја 1980. године) представља основ тезе о „улози личности" као основног разлога за дезинтеграцију земље. Као што то Дејан Јовић сумира ${ }^{19}$, према овој теорији кризу легитимитета и ауторитета која је претходила распаду земље покренуо је нестанак једине истински југословенске институције - Тита. Последице које је нестанак овог централног симбола изазвао и криза која је настала у тренутку када он у физичком облику више није био ту као гарант континуитета земље могу се сагледати и анализом промена у наративима документарних ТВ серија о Титу које су настале у деценији између његове смрти и почетка рата 1991. године

Иако су Филмске Новости приказиване у биоскопима све до 1988. године, већ током 70-тих година телевизија је преузела примат у јавној комуникацији, а поготову комеморацији историјских догађаја. У години која је уследила после Титове смрти сви југословенски ТВ центри ујединили су се у стварању документарне серије од 20 епизода која се звала Стварање Титове Југославије, тиме што је централно тело звано Југословенска Радио Телевизија (JPT) успоставило специјални заједнички комитет чији је задатак био да надгледа производњу ове серије. У овом периоду телевизија ће произвести и 4 игране серије (понекад у комбинацији са истоименим дугометражним играним филмом, а понекад као више-делне ТВ драме ${ }^{20}$ ) у којима је Тито главни лик: Бомбашки проиес (Бранко Иванда, ТВ3, 1979) где Титов лик тумачи Раде Шербеџија, Игмански мари (Здравко Шотра, 1984), где Тита игра Лаза Ристовски, Дани ABHOJA (Сава Мрмак, ТВСА, 1983) где Тита игра Марко Тодоровић, који такође игра Тита и у Одлазак ратника-повратак маршала (Саво Мрмак, ТВБ, 1985).

Као што Бркљачић доказује у широј анализи Титовог лика у уметничким делима, тако се и репрезентација Тита у овим серијама може анализирати користећи концепт који је развио историчар Стивен Гринблат (Stephen Greenblatt) који је

18 Овај сегмент рада се базира на истраживању спроведеном у оквиру пројекта Screening Socialism: Popular Television and Everyday Life in Socialist Eastern Europe, Универзитета Лофбороу (University of Loughborough) у Великој Британији, чији је носилац професор др. Сабина Михељ. Ауторка је захвална на њиховој подршци.

19 Jović, D. (2001) The Disintegration of Yugoslavia - A Critical Review of Explanatory Approaches, European Journal of Social Theory, 4(1), London: SAGE, p. 112.

20 Снимљена је и једноделна ТВ драма Сусрет Тито-Черчил (Дејан Ћорковић,1983) где Тита игра Миша Јанкетић. 
направио дистинкцију између доктринарног формализма и историјског наратива као облика репрезентације ${ }^{21}$. Следећи Гринблата, доктринарни формализам служи томе да представи Истину, а не Историју, чиме се наратив своди на идеологију, јер се присуство приче на коју се алудира намерно брише, а са њом и ситуирање приче у временском контексту. Супротно томе, историјски наратив као облик презентације акценат пребацује са институције на развој историјских догађаја кроз време, на процес уместо на структуру, тиме заправо разоткривајући доктринарни оквир. Доктрирарно формализовање Историје у Истину види се и у Закону о употреби имена и лика Јосипа Броза Тита ${ }^{22}$ који је изгласан 1984. године и којим се прописују начини на који се Титово име и лик могу користити не само у јавном просторима, већ и третирати у креативним продукцијама.

Ако је на почетку 80-тих Титово симболичко тело представљало владајући систем Истине, до краја деценије темељи те 'Истине' почели су да пуцају. Као контраст међурепубличкој сарадњи оствареној на серији 1981. године, 1988. године републички ТВ центри се расправљају око производње комеморативне документарне серије под насловом 70 година Југославије (касније преименована у Југославија по вољи народа). Замишљен као серија од осам епизода, пројекат је требао да покрије југословенску историју од 1918. године. Проблеми су настали када се ТВ Љубљана успротивила да ће тиме бити дат превелики значај догађајима везаним за стварање Југославије, а завршио се тиме што се неколико републичких ТВ центара оглушило о налог Програмског одбора ЈРТ да серију симултано емитују.

Неслога није била очигледна само у расправама о значају одређених историјских догађаја и у разилажењу републичких ТВ центара око заједничке политике производње и емитовања комеморативних документарних серија. Она се ускоро проширила и на оспоравање Титове симболичке позиције у центру друштвеног уређења. Тако је измена Закона о употреби имена и лика Јосипа Броза Тита 1990. године изазвала велика негодовања у јавности, која је критиковала Закон. Проблем је био што би по том закону свака студија или емисија о Титовом лику и делу могла бити проглашена за кривично дело, ако се она не би допала власти. Закон

21 Brkljačić, М. нав. дело. За оригинални текст видети: Greenblatt, S. The Wound in the Wall, in: Practicing New Historicism, eds. Gallagher C. and Greenblatt, S. (2000), Chicago - London: The University of Chicago Press, p. 75-109.

22 Већ у Закону из 1977. године који је прописивао употребу државних симбола, постојала је оваква одредба. Види Пејић, Б. нав. дело. 
је нападан по основу његове противуставности јер се њиме ствара култ покојника, а Тито не може бити равноправнији од других грађана Југославије.

\section{0-те: Тито у 'етно-нациионалистичком' периоду}

Титова Југославија нестала је у деценији након избијања крвавог грађанског рата 1991. године, а са распадом државе настао је и период брисања југословенског сећања и поновног писања југословенског наратива у служби државотворних интереса земаља које су настале из распада федерације. Као што је Дејан Јовић описао, у периоду транзиције и консолидације „спрега између 'стварне моћи' и моћи да се доминира над симболима, сећањима и заборавом остаје ја$\kappa^{23}$ " и нове политичке елите које су дошле на власт стога контролишу наративе о прошлости.

У периоду од 1991. до 2000. године, који се често описује као ‘етнонационалистички’ период обележен грађанским ратом и националистичким дискурсом, културна политика и продукција била је обележена темама за које се сматрало ‘да су од националног значаја' новонасталим државама, које су посегле у прекомунистичке историјске митове да би легитимисале своје национално устројство. Заједничка одредница нових политичких наратива била је дискредитовање југословенског периода, који је описан као 'тамница народа' у којој су политичке и верске слободне биле подређене социјалистичком систему и савезној држави. Јавна иконографија политичке културе која се у великој мери ослањала на комеморацију је уклоњена - споменици Титу и другим народним херојима су склоњени, имена школа, улица и других јавних простора који су носили имена партизанских бораца су промењена, социјалистички државни празници су укинути. Телевизија је играла изразито пропагандну улогу у периоду грађанског рата, а промене у продукцији су пратиле политичке промене, док је филмска производња доживела системски колапс, и пренета је у оквир приватне продукције независних продуцентских кућа а као нови извор финансирања (пре свега у документарној сфери) појавиле су се асоцијације независних новинара и невладине организације (као што су Продукција Б92 у Србији и Factum у Хрватској).

Титов лик је у продукцијама из овог периода ретко евоциран, али постоје два филма где његов лик носи драматуршки ток приче. У питању су играни филм Мармал (Винко Брешан, 1999, Хрватска) и документарни филм Tито по други

23 Jović, D. (2004) Official Memories in Post-Authoritarianism: An Analytical Framework Journal of Southern Europe and the Balkans, 6 (2), p. 98. 
nут међу Србима (Желимир Жилник, 1994, Србија). Маја Бркљачић указује на то да се оба филма поигравају са идејом Титовог повратка 'са онога света', и са друштвеним реакцијама на његово појављивање ${ }^{24}$.

\section{После 2000. године- праксе сећана}

Година 2000. представља међицу у политичкој клими на простору бивше Југославије. Са политичким променама у Хрватској и „демократском револуцијом” у Србији којом је Слободан Милошевић отишао са власти, политичка клима је постала проевропска, и процеси европске интеграције су се почели одвијати паралелно са транзицијским процесима. Овај период обележило је и реструктуирање кинематографске делатности (скоро све бивше југословенске републике су усвојиле нови Закон о Кинематографији у периоду 20052008) и комерцијализација телевизијског тржишта, што је резултовало порастом аудиовизуелне продукције. Трансформација система финансирања и подршке културе је значила стварање филмских центара и комисија, што је стабилизовало нивое продукције. У овом контексту независна продукција документарних филмова се изместила од невладиних организација ка независним продуцентским кућама и великим телевизијским станицама.

Ако је период 1991-2000. године био обележен националистичким пројектима дистанцирања од југословенског политичког наслеђа, период после 2000. године може се описати као период потраге за новом позицијом Југославије у јавном и културном сећању. Као што је Дубравка Стојановић показала, антикомунизам и ревизија прошлости су у Србији коришћени као инструменти национализма током и после Милошевића, када су се те тенденције можда чак и појачале. У смислу измењеног политичког дискурса, Милошевићев режим се сматра комунистичким, те се „демократске промене” после 2000. године могу представити као победа „демократске опозиције” над комунизмом. Тиме опозиција постаје легитиман носилац националне идеје. Стојановић пише да су „на овај начин политичке партије које су формирале нову власт у Србији 2000. године, могле да се представе као 'прави борци за националну ствар', што представља нову идеолошку замку за људе у Србији". Овакви ревизионистички дискурси се манифестују кроз оспорене комеморативне ритуале, одсликавајући промене у култури и у култури сећања,

24 Brkljačić, M. (2002) Tito's Bodies in Word and Image, Narodna Umjetnost, br. $40(1)$, str. 116. 
као „повратак сећању” који обележава когнитивне и емотивне димензије друштвене транзиције и трансформације.

Теоретичари који проучавају питање мобилизације културних пракси у бившим југословенским заједницама, као што су Зала Волчић, Драган Клаић, Митја Великоња и Тодор Куљић, су поставили теоријске претпоставке да се сећање о овом периоду смешта између два пола - национализма у облику националистичких апропријација и потрошачке (конзументске) праксе. Клаић сматра да је културно наследство „инструментализовано као извор националног идентитета и као ресурс за културни туризам" 25 , оцена коју даје и Зала Волчић која додаје да се праксе сећања могу ситуирати између „пракси конзумеризма и национализма/патриотизма ${ }^{26 "}$. Ова два тренда су уочљива у продукцији документарних серија у бившој Југославији, пре свега јавних сервиса у Србији и Хрватској.

\section{Историја на малим екранима}

Анализа продукције документарних серија од стране јавних сервиса пружа увид у начин на који се јавно (колективно) сећање третира и комеморијализује путем малих екрана. Списак кључних документарних серија о историји Југославије које су произвели јавни сервиси бивших југословенских република у последњих десетак година осветљава приступ којим се тематика прошлости заједничке земље обрађује, поготову када се узме у обзир да је у једном тренутку у продукцији било чак пет серија које су се бавиле председником Републике.

- Tuто: ирвено и ирно (1943-1980), производња РТС и Нира, режија Мића Милошевић, 15 епизода (у трајању од 56 минута), емитовано у мају 2006. године (4. маја, на 26-годишњицу Титове смрти), репризирано у априлу 2010. године;

- Tumo, производња Хрватска Радио Телевизија (HRT) и Медитеран Филм, режија Антун Врдољак, 12 епизода документарно-игране структуре (у трајању од 45 минута), емитовано у марту 2010. године;

- Tuто, последњи сведочи тестамента, производња Кинодокумент, режија Лордан Зафрановић, 13 епизода

25 Klaić, D. Remembering and forgetting Communist cultural production, in: Heritage, memory, identity, eds. Anheier, H. and Isar, Y. R. (2011) London: SAGE, p. 185.

26 Volčić, Z. Post-Socialist Recollections: Identity and Memory in Former Yugoslavia, in: Heritage, memory, identity, eds. Anheier, H. and Isar, Y. R. (2011) London: SAGE, p. 188. 
(у трајању од 56 минута), емитовано на HRT у јануару 2012. године;

- Југословенске тајне службе, производња HRT, режија Миљенко Мањкас, емитовано у јуну 2012. године (одмах након завршетка емитовања серије Тито, последњи сведоци тестамента, у истом термину);

- Југославија - држава за једно стољеће, производња HRT, режија Лука Митровић, 20 епизода (у трајању од 30 минута), снимљено 2007. године, емитовано у лето 2012. године

Чак и сам попис наслова главних документарних серија омогућава увид у приступ којим се југословенска социјалистичка прошлост обрађује. Једна од доминантних тема у документарним (или документарно-играним) серијама које су емитоване од 2000. године до данас јесте фокусирање на Јосипа Броза Тита као централне личности која је одредила овај историјски период, и која се поставља као кључ разумевања природе тог политичког система и друштвеног уређења. У две серије, заједно са документарним материјалима проткани су играни делови, а у обе лик Тита игра глумац Борис Свртан. Значајно је истаћи да, иако се неколико поменутих серија издашно користило сировим материјалима сниманим почетком 70-тих за документарну серију Tuтови мемоари (у режији Вељка Булајића, снимана од 1972. године), према постојећој евиденцији, ниједна историјска документарна серија произведена у периоду СФРЈ није реемитована на јавним сервисима након распада Југославије.

Важност ових серија за њихове емитере се види у томе што је већина емитована у 'прајм-тајму' (на пример Зафрановићев Тито, последюи сведоци тестамента емитован је на HRT понедељком у 20:30), и што су им често на располагање стављени значајни ресурси - у случају Врдољакове серије Tuто, HRT је уложила милион евра у пројекат (држава и град Загреб су уложили још пола милиона евра), што га чини најскупљим пројектом у историји хрватске телевизи$\mathrm{je}^{27}$. Други заједнички чинилац за ове серије јесте велика медијска промоција која је претходила њиховом емитовању. Окосница промоције ових серија била је то да оне представљају „коначно суочавање с правом историјском истином ${ }^{28}$.”

27 Zebić, E. Bulajić tuži Hrvatsku televiziju zbog serije o Titu, Radio Slobodna Evropa, 21. april 2010., 13. jun 2013., www.slobodnaevropa.org/articleprintview/2020482.html

28 Pavlić, Z. Je li Miljenko Manjkas prevario gledatelje HTV-a?, TV Kritika Zrinke Pavlić, 3. april 2012., 13. jun 2013., www.tportal.hr/showtime/ tv/185874/Je-li-Miljenko-Manjkas-prevario-gledatelje-HTV-a.html 
За потребе ове анализе је значајно оно што су биле кључне тачке те промоције, а то је велики акценат који је стављан на чињенице, документацију и архивски документарни материјал којим аутори располажу, као и на обимно архивско истраживање које је спроведено. Тако на пример Антун Врдољак у једном интервјуу каже: „Да бих направио овај филм, морао сам прочитати сто двадесет књига, прегледати београдски архив и архив Коминтерне ${ }^{29}$ ". У медијским најавама пре почетка емитовања, редовно су навођена имена историчара који су на њима сарађивали: историчар Предраг Марковић, сарадник на серији Тито: Црвено и ирно, историчар Иво Банац био је сарадник на серији Тито, историчар Предраг Јурчевић био је стручни сарадник на серији Југословенске тајне службе, а на Тито, последюи сведоци тестамента као сарадници се наводе чак три историчара: Иво Голдстеин и Твртко Јаковина из Хрватске и Дејан Јовић, што је истицано као валидација њихове историографске озбиљности ${ }^{30}$.

Серију Tито: ирвено и ирно, РТС је најавио као „капитални лексикон епопеје и аристократије Јосипа Броза, од бољшевизма до уставног национализма друге Југославије”, истичући да „после годину и по дана истраживања и разговора са стотинак важних сведока историје и антиисторије, грађана целе некадашње Југославије, стиже прича о комунистичком вернику и јеретичком комунисти, највећем бренду земље које више нема", и да је намера аутора да „да што верније прикажу лице и наличје педесетогодишњег историјског трилера... Сведоци - поклоници, противници и дистанцирани посматрачи - објасниће како је један човек могао да буде терориста, ослободилац, просвећени монарх, велики светски лидер и балансер између блокова, бонвиван и ловац, идеолошки вођа, гарант мира и јединства многонационалне државе, борац против Стаљина, последњи Хабзбург, рођени макијавелист, обожавани диктатор ${ }^{31}$ ".

Врдољакова документарно-играна серија о Титу снимана је три године, и тематски покрива цео Титов живот, од детињства до његове смрти 1980. године. Када је најављивана требала је да садржи ексклузивне интервјуе са бившим америчким председником Картером (Jimmy Carter), као и британском премијерком Маргарет Тачер (Margaret Thatcher),

29 Jović, J. (21. novembar 2009) Antun Vrdoljak: Moj će film biti porazan za zločinca Tita, Slobodna Dalmacija.

30 Mamić, Z. (04. mart 2006) Tito kao brend i fenomen, Novi List.

31 Anonim, Tito, Crveno i crno (1943-1980), najava programa, RTS, 12. april, 2010, 13. Jun 2013, www.rts.rs/page/tv/sr/story/20/RTS+1/620921/Tito:+Crveno $+\mathrm{i}+\mathrm{crno}+(1943-1980) \cdot \mathrm{html}$ 
али су кључни коментатори у серији заправо хрватски историчар Иво Банац и српски публициста Перо Симић ${ }^{32}$. Серија садржи број играних секвенци које представљају историјске сцене за које не постоје документарни снимци, али по тврдњама глумца који тумачи лик Тита, Бориса Свртана: „важно је нагласити да су све те сцене снимљене према документарним материјалима, редатељ је инсистирао на томе да поштујемо сваки зарез, свако слово ${ }^{33}$."

Истоимена серија о Титу аутора Лордана Зафрановића рађена је, према изјавама аутора, пет година, и у тринаест епизода покрива период од готово седам деценија. ,УУ њој су своје исказе и исповести везане за ову епоху дале око 60 личности, међу којима су и прва Титова супруга Херта Хас, која је први пут јавно проговорила, Миша Броз, Оскар Данон, Олга Хумо $^{34}$ ", а како пише у продуцентском саопштењу за медиje: „најближи чланови обитељи, жене, пријатељи и сурадници, али и политички противници, испричали су своје приче искрено и отворено, с временском дистанцом, без вела тајни, идеологије и мита, посредно - изговарали су властите судбине, а посебно доживљаје, догађаје и искуства из живота и рада с Титом ${ }^{35}$." Главна ауторска одредница ове серије је што су за њене протагонисте одабрани људи који су били блиски Титу, и њихова сећања су тематски груписана, без повезаних текстова или спикерског 'оф-а' који би описане догађаје контекстуализовали. Емитовање серије обележио је и медијски веома пропраћен судски процес између новинарке Мире Шувар (удовице некадашњег хрватског политичара из доба СФРЈ, Стипе Шувара) која је обавила велики део интервју за серију, и тужила аутора и продуцента Зафрановића због тога што се одлучио „више бавити Титовим интимним животом, а не идеологијом ${ }^{36}$ ".

Југославија - држава за једно стољеће је серија која је снимана у продукцији HRT између 2001. и 2006. године, али је након завршетка „бункерисана” пуних пет година, пре него што је коначно емитована 2012. године, такође у контексту судског спора, овог пута између аутора Луке Митровића и

\footnotetext{
32 Zebić, E. nav. delo.
}

33 Anonim, Vrdoljakova osveta Titu, BL!N Magazin: Kultura, 16. januar 2010., 13. jun 2013., www.banjalukain.com/kultura/vrdoljakova-osveta-titu

34 Anonim, Zafranović: Svi ćemo biti kolonija, Filmske radosti, 3.decembar 2012., 13. jun 2013., http://www.filmske-radosti.com/Vesti/Zafranovic-Svicemo-biti-kolonija

35 Jasprica, O. Dokumentarna TV serija TITO Posljednji svjedoci testamenta, 13. jun 2013., www.lordanzafranovic.com/hrv_tito.html

36 Romić, T. (30. decembar 2011) Unatoč zabrani, HRT će prikazati Zafranovićev dokumentarac o Titu, Večernji list. 
ТВ куће због неуважавања његових ауторских примедби на коначну верзију серије ${ }^{37}$. Одлика ове серије је импресиван списак међународних саговорника укључујући Михаила Горбачова, америчког геостратега Збињева Бжежинског (Zbigniew Brzezinski), и бившег талијанског шефа дипломатије Ђанија де Микелиса (Gianni de Michelis), и док је једна епизода целокупно посвећена Титу, серија је добила комплименте због тога што аутор „није опсједнут једном личношћу попут Врдољака и Зафрановића већ се доиста документаристички бави државом која је одређивала судбине наших живота тијеком цијелога 20. стољећа, чак и онда када више није постојала ${ }^{38}$ ".

Аутори који потписују „часове историје” на јавним сервисима могу се генерацијски груписати. Редитељ серије Tито: ирвено или ирно Мића Милошевић, рођен је 1931. године, исто као и редитељ Антун Врдољак, док је редитељ Лордан Зафрановић рођен 1944. године. Као аутори дакле припадају директним сведоцима земље чијом се историјом баве, али чињеница да су управо они приступили обради ове теме уз подршку јавног сервиса указује на то да је званични наратив прошлости у рукама старије генерације.

Антун Врдољак је свој приступ теми описао у једном интервјуу: „Нисам послу пришао с предрасудама, него сам тражио искључиво чињенице и истину утемељену на чињеницама... То није филм против Тита нити ми је то била накана. То је филм за повијесну истину, а она је, морам признати, за Тита крајње поразна. Једноставно, ријеч је о злочинцу каквих је свијет мало видио". 39 Занимљиво је да је Врдољак, као потписник два филма из партизанског жанра снимљених уз подршку власти у периоду СРФЈ, који је потом изјавио да је на вест о Титовој смрти славио шампањцем, данас инсистира на објективности свог приступа: „Ја немам право некога вољети или не, па тако и Тита. У овом се филму неће изговорити ни једна реченица која није поткријепљена најпоузданијим документима. О Титу ће говорити повјесничари, и они који су га ватрено љубили и они који имају резерве. О њему ће говорити људи који су га познавали, који су били у његовој близини, који су се с њим дружили ${ }^{40}$."

37 Ćustić, M. (05. april 2001) Serijal o Jugoslaviji već pet godina u bunkeru HRT-a, Nacional, br. 803.

38 Ribarić, Z. Dokumentirana Jugoslavija, Online, 11. jun 2012., 13. jun 2013., www.online.hr/gledaj/dokumentirana-jugoslavija/

39 Jović, J. (21. novembar 2009) Antun Vrdoljak: Moj će film biti porazan za zločinca Tita, Slobodna Dalmacija.

40 Anonim, Vrdoljakova osveta Titu, нав. дело. 
Аутор серије Тито: ирвено и ирно, Мића Милошевић, изјавио је да је серија „рађена без идеолошког дописивања и отписивања, заснована на стриктно аутентичним чињеницама и мотивисана харизмом Јосипа Броза Тита ${ }^{41}$ ” и да је циљ серије „да да̂ објективне одговоре на нека питања која до сада ни историчари нису постављали ${ }^{42}$ ". Занимљива је ауторова изјава која открива његов поглед, и приступ употреби архивског материјала: „како је сав документарни материјал из овог периода апологетски, постојала је опасност да се не упадне у ту матрицу ${ }^{43}$." Слично неповерење спрам слике исказује и историчар Предраг Марковић, сарадник на овој серији који додаје да она „има нов приступ самој историји... Апологетски, свечарски, идолатријски дискурс Титових година, какав је уосталом и сав визуелни материјал из тог времена, који је у каснијим годинама замењен потпуном негацијом тог времена и лика и дела Јосипа Броза, у овој серији даје уравнотежену слику и историјских догађаја и главног актера Јосипа Броза Тита ${ }^{44}$ ".

Са своје стране, Лордан Зафрановић је у изјавама за медије тврдио да покушава да покаже Тита као једног „обичног необичног човјека", без цензуре и без идеолошког опредјељења ${ }^{45}$ : „Покушао сам да поставим Тита за обитељски сто и да га проматрамо као дио једне велике фамилије, са свим његовим врлинама и свим манама ${ }^{46 "}$ описујући свој приступ као ,један поетски поглед на Тита, не пјеснички, него поетски индивидуални поглед који оставља гледаоцу да сам доживи и ту епоху и тог владара ${ }^{47}$ ".

Коментаришући феномен да се у једном тренутку у продукцији налазило чак пет документарних серија о Титу, историчар и академик Душан Биланџић изјавио је: „Иако ми је мало необично што се одједном снима толико филмова о Титу, дијелом ми је и разумљиво јер се страсти које су владале овим просторима полако смирују. Међутим, без обзира

41 Anonim, Tito, Crveno i crno (1943-1980), najava programa, RTS, 12. april, 2010, 13. Jun 2013, www.rts.rs/page/tv/sr/story/20/RTS+1/620921/Tito:+Crveno $+\mathrm{i}+$ crno $+(1943-1980) \cdot \mathrm{html}$

42 Ast. S. (4. maj 2006) Televizija: Crveno i crno, Vreme br. 800.

43 Исто.

44 Исто.

45 Jasprica, О. нав. дело.

46 Albijanić - Duraković, A. Lordan Zafranović: Danas u Zagrebu za mene kažu da sam izdajnik, a ja mislim da sam hrvatskom narodu spašavao bar mali dio obraza!, 26 novembar 2011, 22. jul 2013., www.neznase.ba/intervju/intervju/9969-lordan-zafranovi-danas-u-zagrebu-za-mene-kau-da-sam-izdajnika-ja-mislim-da-sam-hrvatskom-narodu-spasaao-braz.html

47 Исто. 
на то тко радио филмове, сумњам да ће успјети дати праву и заокружену слику о Титу. Не мислим тако због неких идеолошких разлога, него због чињенице да то није могуће без давања цјеловите анатомије друштва, а људи, за које знам да раде на филмовима, једноставно нису у стању ући у суштину проблема. Уосталом, то још није успјела нити хисториографија ${ }^{48}$."

Ако је продукцију и најаву неких од ових серија пратила контроверза и судски спорови, занимљиво је анализирати реакције јавности након емитовања првих епизода. Статистика гледаности показује да је приликом почетка емитовања владало велико интересовање за ове серије. Гледаност прве епизоде Врдољакове серије била је 22.6 посто, док је на крају емитовања пала на 8 посто, што је ту епизоду учинило најслабије гледаним програмом од свих емитованих те недеље на првом програму HRT-а у термину у 8 увече ${ }^{49}$. Зафрановићев Тито је такође постигао гледаност од 10.3 посто на почеку емитовања, али није успео да одржи интересовање публике. Делимично објашњење се може приписати критици коју је серија доживела а то је да се редитељ превише интересовао за таблоидно интимне аспекте Титовог живота: „прва епизода могла се комотно звати Заводник Тито и његов 'lifestyle', а ако је цијела серија таква требало би ју преименовати у Тито, подвучено жутим ${ }^{50}$.

Званични протест стизао је и са леве и десне стране политичког спектра. Тако је Савез антифашистичких бораца и антифашиста Хрватске (САБА) у писму највишим државним званичницима затражио престанак емитовања играно-документарне серије Тито редитеља Антуна Врдоља$\mathrm{\kappa a}^{51}$, јер сматра „да то води циљаном распиривању мржње, а емисија срамоти Хрватску и Врдољака као редитеља који није у стању да затоми мржњу према Титу”. Њиховој осуди придружио се бивши хрватски предсједник (и почасни предсједник Савеза антифашистичких бораца и антифашиста Хрватске) Стипе Месић ${ }^{52}$.

48 Mamić, Z. (04. mart 2006) Tito kao brend i fenomen, Novi List.

49 Polimac, N. (12. jun 2010) 'Tito' Antuna Vrdoljaka - konačna presuda, Jutarnji list.

50 Ponoš, T. HTV počeo emitiranje dokumentarca: Tito-podvučeno žutim (Zafranović nadmašio Vrdoljaka), 4. januar 2012., 13. jun 2013., http://novilist. $\mathrm{hr} /$ Scena/TV/HTV poceoemitiranjedokumentarcaTitopodvucenozutim

51 Anonim, U Hrvatskoj traže prestanak emitovanja serije Tito, Politika online, 5. maj 2010., 13. Jun 2013., http://www.politika.rs/vesti/najnovije-vesti/uHrvatskoj-traze-prestanak-emitovanja-serije-Tito-i133638.1t.html

52 Anonim, Bulajić tuži Hrvatsku televiziju zbog serije o Titu, Radio Slobodna Evropa, 21. april 2010, 13. jun 2013., http://www.slobodnaevropa.org/con- 
На Зафрановићеву серију реакције су дошле са супротне стране. Тако је Обрад Косовац (један од сарадника на документарно-играној серији Југославенске тајне службе коју је један број ТВ критичара пак оптужио за „хорор” приказ “о свим страхотама комунизма због којих се морамо срамити што смо живјели у том режиму ${ }^{53}$ ") изјавио да у Зафрановићевој серији „галерија личности из јурског парка у филму говори позитивно о Титу ${ }^{54}$ ". На ову серију реаговала је и Удруга бранитеља, инвалида и удовица Домовинског рата Подравке (УБИУДР) која је затражила прекид емитовања због тога што сматрају да се тиме периоду Титове Југославије посвећује сувише пажње: „Несхватљиво је и то да је за ову серију одобрено чак 13 епизода (свака у трајању од сат времена!), док с друге пак стране о хрватском Домовинскоме рату, првом хрватском предсједнику др. Фрањи Туђману и људи који су у крви створили слободну, самосталну и неовисну хрватску државу та иста телевизија даје прилоге “на капаљке”, и у времену кад је најмања гледаност. Чуди нас од хрватских редатеља, попут Зафрановића, да их „не занимају” теме попут Вуковара, Шкабрње, Книна, рушења Дубровника, српских концентрацијских логора, протјеривања пола милијуна Хрвата из својих домова и слично ${ }^{55}$."

У чланку објављеном 2009. године новинар Тим Џуда (Тim Judah) износи тезу да је након распада Југославије наставила да постоји географска и културолошка област коју он описује као Југосфера, у којој су се обновиле економске и политичке везе некадашње земље, пре свега захваљујући чињеници да „највећи број људи унутар Југосфере говори исти језик". Џуда наводи бројне примере оног што је заједничко људима који живе у Југосфери, као што су исти укус у храни, музици, култури и бизнису, али и „одбијање да се препозна ово заједништво.” Сложеност ових односа може се приметити и у реакцијама на емитовање документарних серија између различитих република. Југосфера се одликује и у томе што се телевизијски програм широм бивше Југославије може пратити путем кабловске телевизије, али и разменом између ТВ станица. Тако је серија Тито: ирвено и ирно приказана у БиХ, а Зафрановићева серија откупљена за емитовање у Словенији, али и мимо тога, путем кабловске телевизије, велики број гледалаца у Хрватској је погледао

tent/serija_tito_bulajic_vrdoljak/2020482.html

53 Pavlić, Z. нав. дело.

54 Ponoš, Т. нав. дело.

55 Anonim, Nakon Tita: OZNA i UDBA, Hocemocenzuru Blog, 04. april 2012., 13 jun 2013., blog.dnevnik.hr/print/id/1630522870/nakon-tita-ozna-i-udba. html 
серију Тито: ирвено и ирно, која није била откупљена од стране HRT-a ${ }^{56}$. Посебно је занимљиво дакле, пратити реакције јавности које прелазе границе бивших југословенских република.

У Словенији је поводом емитовања серије Тито, последњи сведоии тестамента Лордана Зафрановића у прајм-тајм термину (недељом у 20:00) избила реакција од стране странака десног центра. Носилац ове кампање био је недељни лист Репортер који се после емитовања прве епизоде огласио са тврдњом да је „скандалозно то што се у серији Тито и бивши комунистички режим представљају некритички, те што умјесто Зафрановићева серијала није откупљена објективнија серија ‘Тито’ редатеља Антуна Врдољака, у којој наступају и словенски повјесничари који с критичком дистанцом говоре о Титу, поратним ликвидацијама и обрачунима с идеолошким противницима Тита и тадашњег режима ${ }^{57 "}$. Међутим, према подацима словеначке телевизије, интересовање за Зафрановићеву серију у Словенији је било доста високо, јер је прву епизоду гледало је 178.000 људи - 9,7 одсто популације старије од 10 година, односно 21 проценат оних који су у том термину били пред ТВ екранима, што је било на нивоу гледаности у Хрватској. Руководство словеначке телевизије је нападано и због тога што је претплатило вредност серије, али и због тога што су потписали уговор с продуцентима спорне серије 28. јуна, односно „на Видовдан српски и старојугославенски државни празник ${ }^{58 \%}$.

Серија Тито: ирвено и ирно приказана је скоро паралелно на РТС и на Централној федералној телевизији (ФТВ) у Босни и Херцеговини. Већ после прве епизоде у БиХ уследили су напади не само на ауторе него и уреднике телевизије који су ову серију откупили за емитовање. Тако је Управни одбор Савеза друштава „Јосип Броз Тито” упутило отворено писмо директору ФТВ у коме је стајало: „Након емитирања првог наставка овог серијала, у великом броју средина широм БиХ, у редовима бораца НОР-а, грађана, а посебно младих, серија је оцијењена као грубо негирање истине о народноослободилачкој борби и доприносу народноослободилачке војске, побједи антифашистичке коалиције и неистина о читавој епохи под вођством маршала Тита, те

56 Polimac, N. нав. дело.

57 Kršinar, I. (22. oktobar 2012), Zgodovinarji se zgražajo nad dokumentarcem o Titu, Reporter.

58 Kršinar, I. (11. decembar 2012) Preplačana ideološka serija o Titu, Reporter. i Anonim, Zafranovićev Tito posvađao Slovence, 11. decembar 2012., 13. jun 2013., www.tportal.hr/vijesti/svijet/231226/Zafranovicev-Tito-posvadao-Slovence.html 
посебно о улози Тита, врховног команданта партизанских одреда НОР-а и предсједника Југославије ${ }^{59}$."

Новинар Сенад Печанин коментарисао је да ,је јасно да се ради о серијалу који, скривајући се иза претенциозне најаве објашњавања стварне улоге и дјела Јосипа Броза, за циљ има телевизијску „научно-новинарску, документаристичку” ревалоризацију хисторијске улоге Драже Михаиловића и четничког покрета у Другом свјетском рату ${ }^{60}$. Некадашњи председник СР Босне и Херцеговине Раиф Диздаревић написао је: „Тврдња аутора да је то покушај да се наслика једна уравнотежена слика тог времена и његовог главног актера Јосипа Броза Тита је подвала. Нескривена је и огољена намјера да се у што већој мјери прикаже црним и то вријеме и Тито. Често са позиција милошевићевске и прочетничке политике и пропаганде ${ }^{61 "}$.

Реакција Јасмина Дураковића, генералног директора ФТВ-а, била је интересантна по томе што он није бранио одлуку о емитовању серије позивањем на њену истинитост или објективност, већ тиме да је: „документарна серија Tито: црвено и ирно узета за емитирање управо из разлога покушаја отварања расправе о улози Јосипа Броза у 20. стољећу. Били смо свјесни да ће серија изазвати реакције јер изражава вриједносне судове који произилазе из актуелног српског (или београдског) погледа на личност Јосипа Броза, никако не ставове и опредјељења ФТВ-а...ФТВ је у јавности и препозната као медиј који има прогресиван став када је у питању наша садашњост, али и прошлост и будућност, те као медиј који има довољно ширине да буде и демократска трибина различитих мишљења ${ }^{62}$." Међу онима који су сматрали да је приказивање било оправдано, нашао се и Хамза Кашић који је скренуо пажњу на то да се ниједна телевизија још није показала спремном да емитује документарне серије и филмове о Титу који су настали у периоду СФРЈ ${ }^{63}$.

\section{Водччи кроз $\mathrm{Yu}$}

Друга уочљива група документарних серија које су емитовали јавни сервиси или телевизије са националном

59 Anonim, Prekinuti emitiranje serije Tito - crveno i crno, FENA, 11. maj 2006, 13. Jun 2013., http://www.klix.ba/vijesti/bih/prekinuti-emitiranje-serije-tito-crveno-i-crno/060511037

60 Pećanin, S. (13. maj 2006) Četničkom protiv komunističke propagande o Titu, Dani.

61 Исто.

62 Исто.

63 Исто. 
фреквенцијом од 2000. године су серије које се баве југословенском популарном културом, попут серија: Како смо забављали Тита, производња Радио Телевизија Србије (РТC) и Филмске Новости, аутор Миња Субота, 8 епизода, емитовано 2003. године; Фудбал, ногомет и још по нешто, производња Absinthe Production, аутор Игор Стоименов (р. 1971. године), 9 епизода, емитовано у априлу 2007. године на ТВ Б92; Робна кућа - за некога све, за свакога по нешто, производња РТС, аутор Игор Стоименов, 12 епизода, емитовано у марту 2009. године; СФРЈ за почетнике (Do You Miss Yu?), производња Visionary Thinking и ТВ Б92, аутор Радован Купрес, 16 епизода, емитовано у септембру 2011. године. У погледу њихових дискурзивних аспеката ове серије оне се могу супротставити првој групи анализираних серија које настоје да одреде објективне историјске истине о правој природи Титове Југославије. Као контраст, ова група серија нуди успомене о свакодневном животу у комунизму, често са хумористичким призвуком - представљајући предмете из некадашње потрошачке корпе, разне друштвене и културне праксе, идеолошке симболе, хероје и артефакте популарне културе, и тиме спроводећи у суштини неку врсту „ре-брендирања” Југославије за нове (младе) генерације потрошача.

Најава серијала СФРЈ за почетнике даје опис овог приступа: „150 обичних и необичних људи, познатих и непознатих, радника, сељака, поштене интелигенције и уметника открива како је било кад су били Југословени: шта су јели, шта слушали, на кога су се палили, колико су имали новца...” Аутори серије су јасно најавили да се емисије базирају на приватним сећањима, и да их не занима ни службена историографија ни идеолошке анализе: СФРЈ за почетнике је документарно забавни серијал, колажног типа о феноменима везаним за културу свакодневице у Другој Југославији. Свих 16 епизода базира се на приватним сећањима јавности познатих и непознатих личности које су живеле или одрасле у СФРЈ. Кроз 150 интервјуа сниманих у свим бившим Републикама и велику количину занимљивог архивског материјала дочарава се више од стотину појмова (појава, личности, производа, ритуала...) који су бојили живот у некадашњој Југославији". Титу је посвећена цела једна епизода у серији Робна кућа, али већ сам назив даје индикацију о приступу: „Тито - поп икона”.

У погледу успеха у „Југосфери”, добар пример је серијал СФРЈ за почетнике, који је и у свом продукцијском концепту захватио простор ,југосфере” истичући у најави да су интервјуи са саговорницима снимани у „у свим бившим 
Републикама". Успех тог приступа види се и у дистрибуцији јер је серијал, који је премијерно емитован на телевизији Б92 у Србији, остварио и регионални успех и приказан на црногорској телевизији Вјести, бањалучкој Алтернативној телевизији и хрватској Независној телевизији.

Одређујући како ове серије третирају питање културе сећања на простору бивше Југославије, може се рећи да оне функционишу као конзументски облици носталгије, које је Зала Волчић описала као „туристички” однос према историји. Дубравка Угрешић је прва употребила термин „Југоносталгија" да опише одређене процесе сећања у Југославији, али остаје питање да ли се ова носталгија може описати као политички став. Позивајући се на дистинкцију коју је Светлана Бојм (Svetlana Вoуm) направила између ресторативне и рефлективне носталгије, остаје нејасно да ли се сентименту Југоносталгије може приписати управо „ресторативна” функција, у најмању руку у смислу очувања културног сећања (cultural memory) и историје Југославије. У својој анализи различитих приступа југословенској прошлости Тања Петровић је описала овај приступ као „индустрију комунистичког искуства", називајући редукцију југословенског искуства на деполитизовану причу, племенску сентименталност, кич колекционарство предмета из социјалистичког времена и бизарне комеморативне праксе „ефикасним начином да се југословенско искуство искључи из преговара наше садашњости и будућности ${ }^{64}$ ".

\section{Закључак}

Можда најиндикативнија изјава аутора ТВ серија и документарних филмова анализираних у овом раду, она која највише открива угао из ког они приступају анализи југословенске прошлости, јесте подозорење од документарних слика прошлости. Када аутор серије Тито: ирвено и ирно истиче „опасност да се упадне у матрицу апологетског материјала" којим се илуструје наратив, то указује на то да се аудиовизуелној слици прошлости прилази као историјском сведочанству, који треба да верификује друге историјске документе.

Међутим ако се филмска слика прихвати као „место сећања”, као актер историје, а не њен (објективан) сведок, отварају се потенцијално нови начини приказивања и анализе прошлости. Увођење појма сећања као теоријског оквира

64 Petrović, T. (2012) Misliti Jugoslaviju u današnjoj Evropi, Beton br.123, 15. maj 2012, 20. avgust 2014, http://www.elektrobeton.net/mikser/mislitijugoslaviju-u-danasnjoj-evropi/ 
подсећа на то да су архивске слике прошлости конструкција настала у одређеном времену, служећи конкретним политичким потребама. Реконтекстуализација историјских слика, и њихово ситуирање у новим аудиовизуелним наративима историје такође захтева и свест, па и истицање, чињенице да се њихова реинтерпретација дешава унутар измењеног савременог контекста који такође поседује своје политичке и друштвене потребе.

У томе лежи и суштина нових развоја унутар саме дисциплине историје, који су се окренули препознавању и прихватању појма репрезентације. Заједно са другим историчарима, Пјер Нора је поставио тезу да је крајем XX века дошло до раскола између нације и колективног сећања, што је довело у питање и до тада легитимне праксе историографије. У пољу историје овај тренутак се назива и 'културни заокрет' (cultural turn), у ком као што је то сумирао историчар Вулф Канстајнер (Wolf Kansteiner) концепт сећања омогућава да покажемо како репрезентације прошлости заиста функционишу, и како се моћ репрезентација може објаснити, истраживањем механизама њеног функционисања.

Није случајност што се експлозија мултиплих наратива прошлости и академско проучавање њихове конструкциje десило у тренутку колапса идеолошких блокова Хладног рата, јер су они, како то пише Тодор Куљић, стварали општу културу сећања, пре свега у једнопартијским ауторитарним система који су прошлост писали декретом. Имплозија европског социјализма отворила је нову будућност, али и нову прошлост, која се све теже може предвидети. Некадашња места конструкције сећања, данас постају места деконструкције наратива прошлости. Све док се кроз интерпретацију аудиовизуелне слике тражи коначна Историја и објективна Истина, страх од те слике је потпуно оправдан, а прилика да се кроз медиј аудиовизуелне слике поставе питања о медијским репрезентацијама културе сећања делује за сада пропуштено.

\section{ЛИТЕРАТУРА:}

Boym, S. (2002) The Future of Nostalgia, New York: Basic Books.

Brkljačić, M. (2002) Tito's Bodies in Word and Image, Narodna Umjetnost, br. 40(1), str. 99-127.

Daković, N. Out of the Past: Memories and Nostalgia in (Post)Yugoslav Cinema, in: Past for the Eyes: East European Representations of Communism in Cinema and Museums after 1989, eds. Sarkisova, O. and Apor, P. (2008) Budapest: CEU Press.

Dobrenko, E. (2008) Stalinist Cinema and the Production of History: Museum of the Revolution, Edinburgh: Edinburgh University Press. 


\section{МИЛА ТУРАЈЛИЋ}

Goulding, D. J. (2002, 2nd) Liberated Cinema. The Yugoslav Experience 1945-2001, Bloomington: Indiana University Press.

Greenblatt, S. The Wound in the Wall, in: Practicing New Historicism, eds. Gallagher, C. and Greenblatt, S. (2000) Chicago: The University of Chicago Press.

Hayward, S. Framing National Cinemas, in: Cinema and Nation, eds. Hjort, M. and MacKenzie, S. (2005) London: Routledge.

Jović, D. (2001) The Disintegration of Yugoslavia - A Critical Review of Explanatory Approaches, European Journal of Social Theory, 4(1), London: SAGE, pp. 101-120.

Judah, T. (2009) Yugoslavia is dead, long live the Yugosphere, LSE Papers on South Eastern Europe, London: Crowes Complete Print.

Kansteiner, W. (2002) Finding Meaning in Memory: A Methodological Critique of Collective Memory Studies, History and Theory, 41(2), New York: Wiley, pp. 179-197.

Kennedy, T. (2007) Cinema Regarding Nations: Re-imagining Armenian, Kurdish, and Palestinian national identity in film, doctoral dissertation, Department of Film, Theater ' Television, University of Reading.

Klaić, D. (2011) Remembering and forgetting Communist cultural production, in Heritage, memory, identity, eds. Anheier, H. and Isar Y. R. (2011) London: SAGE, pp. 177-186.

Kuljić, T. (2011) Sećanje na titoizam, Beograd: Čigoja.

Kuljić, T. (2002) Prevladavanje prošlosti-uzroci i pravci promene slike istorije krajem XX veka, Beograd: Ogledi, Helsinški odbor za ljudska prava u Srbiji.

Nora, P. (1984). Entre Mémoire et Histoire - La problématique des lieux, dans Les lieux de mémoire (Vol. 1), Paris: Gallimard.

Olick, J. K. (2007) From Usable Pasts to the Return of the Repressed, The Hedgehog Review: Critical Reflections on Contemporary Culture, Summer 07, Virginia: Institute for Advanced Studies in Culture, pp. 19-31.

Пејић, Б. „Тито” или иконизације једне представе, у Ново читање иконе, приредио Сретеновић, Д. (1999), Београд: Геопоетика.

Petrović, T. (2012) Misliti Jugoslaviju u današnjoj Evropi, Beton br. 123, 15.maj 2012, 20. avgust 2014, http:/www.elektrobeton.net/ mikser/misliti-jugoslaviju-u-danasnjoj-evropi/

Стојановић, Д. Уље на води: Политика и друштво у модерној историји Србије, у Модерна Србија 1804-2004: три виђења или позив на дијалог, приредио Јовановић, М. (2009) Београд: библиотека Сербица - књига 1

Volčić, Z. Post-Socialist Recollections: Identity and Memory in Former Yugoslavia, in Heritage, memory, identity, eds. Anheier, H. and Isar Y. R. (2011) London: SAGE, pp. 187-197.

Wachtel, A. B. (1998) Making a Nation, Breaking a Nation: Literature and Cultural Politics in Yugoslavia, Stanford: Stanford University Press. 
МИЛА ТУРАЈЛИЋ

Mila Turajlić

University of Belgrade, Faculty of Political Sciences, Belgrade

\title{
CULTURE OF REMEMBERANCE OF THE FIGURE OF JOSIP BROZ TITO IN POST-YUGOSLAV DOCUMENARY SERIES
}

\begin{abstract}
The aim of this paper was to analyze the policy of representation of the presidential figure of Josip Broz Tito in the most important TV series after 2000. Following a short review of the role which the audio-visual representation (in film and then television) has played in building the cult of his person in the SFRY period, the main part of the paper examines the thematic and narrative content of relevant TV series related to the discourses inherited from the socialist period which have undergone political and social transition. Critically summing up variable meanings of the presentations of Josip Broz Tito in the context of construction and reconstruction of the culture of remembrance, the main part of the paper examines different existing nationalist/patriotic and consumerist approaches.
\end{abstract}

Key words: culture of remembrance, documentaries, TV series, Josip Broz Tito, personality cult, (post) Yugoslav narratives.

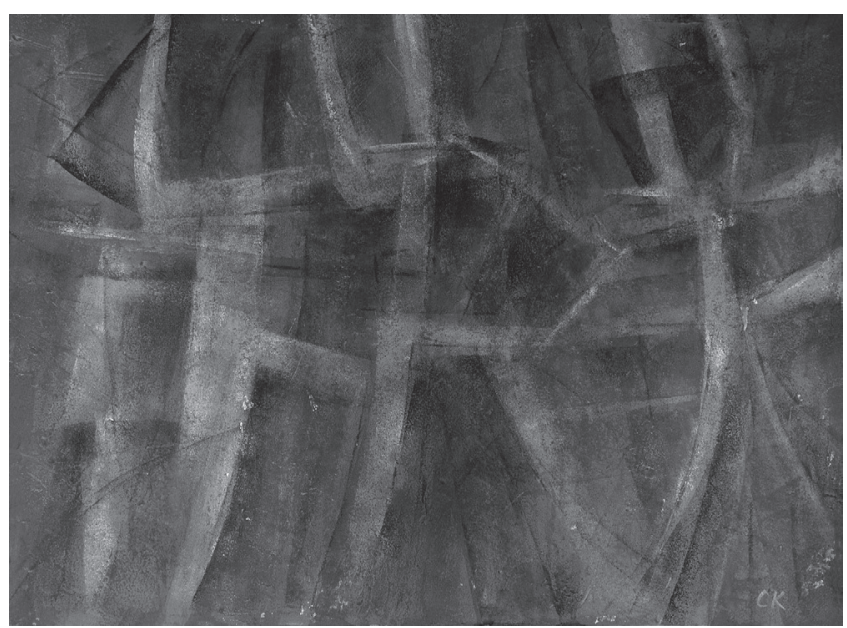

Слободан Каштаварац, Непрестана борба, 2013. 